\title{
North Pacific and North Atlantic sea-surface temperature variability during the Holocene
}

\author{
Jung-Hyun Kim ${ }^{\mathrm{a}, *}$, Norel Rimbu ${ }^{\mathrm{a}}$, Stephan J. Lorenz ${ }^{\mathrm{b}}$, Gerrit Lohmann ${ }^{\mathrm{a}, \mathrm{c}}$, \\ Seung-Il Nam ${ }^{\mathrm{d}}$, Stefan Schouten ${ }^{\mathrm{e}}$, Carsten Rühlemann ${ }^{\mathrm{f}}$, Ralph R. Schneider ${ }^{\mathrm{g}}$ \\ ${ }^{a}$ FB5 Geowissenschaften, Universität Bremen, Klagenfurterstraße, D-28359 Bremen, Germany \\ ${ }^{\mathrm{b}}$ Max-Planck-Institut für Meteorologie, Modelle und Daten, Bundesstrasse 53, D-20146 Hamburg, Germany \\ ${ }^{\mathrm{c}}$ Alfred-Wegener-Institut für Polar- und Meeresforschung (AWI), Bussestraße 24, D-27570 Bremerhaven, Germany \\ ${ }^{\mathrm{d}}$ Petroleum and Marine Resources Division, Korea Institute of Geoscience and Mineral Resources, 305-350 Taejon, Korea \\ ${ }^{\mathrm{e}}$ Royal Netherlands Institute for Sea Research (NIOZ), P.O. Box 59, 1790 AB, Den Burg, Texel, The Netherlands \\ ${ }^{\mathrm{f}}$ Bundesanstalt für Geowissenschaften und Rohstoffe, Referat B 3.23-Meeresgeologie, Stilleweg 2, D-30655 Hannover, Germany \\ ${ }^{\mathrm{g}}$ Département de Géologie et Océanographie, UMR5805-EPOC, CNRS/Université de Bordeaux1, 33405 Talence Cedex, France
}

\begin{abstract}
Holocene climate variability is investigated in the North Pacific and North Atlantic realms, using alkenone-derived sea-surface temperature (SST) records as well as a millennial scale simulation with a coupled atmosphere-ocean general circulation model (AOGCM). The alkenone SST data indicate a temperature increase over almost the entire North Pacific from 7 cal kyr BP to the present. A dipole pattern with a continuous cooling in the northeastern Atlantic and a warming in the eastern Mediterranean Sea and the northern Red Sea is detected in the North Atlantic realm. Similarly, SST variations are opposite in sign between the northeastern Pacific and the northeastern Atlantic. A 2300 year long AOGCM climate simulation reveals a similar SST seesaw between the northeastern Pacific and the northeastern Atlantic on centennial time scales. Our analysis of the alkenone SST data and the model results suggests fundamental inter-oceanic teleconnections during the Holocene.
\end{abstract}

(C) 2004 Elsevier Ltd. All rights reserved.

\section{Introduction}

The oxygen isotope composition of polar ice sheets (e.g., Grootes et al., 1993) suggests a relatively stable Holocene climate when compared to the last glacial and viewed in a long-term perspective. In the context of short-term variability however, significant climate changes have also been identified for the Holocene although their amplitudes are remarkably small in comparison with those during the last glacial (e.g., Bond et al., 2001; Moy et al., 2002; Schulz and Paul, 2002; Oppo et al., 2003).

Recently, reconstructions of sea-surface temperatures (SSTs) for the North Atlantic also showed significant

\footnotetext{
*Corresponding author. Tel.: + 49-421-218-8929; fax: + 49-421-2188916.

E-mail address: jungkim@allgeo.uni-bremen.de (J.-H. Kim).
}

long-term, regionally coherent climate changes throughout the Holocene (Marchal et al., 2002; Rimbu et al., 2003). For the northeastern Atlantic, Marchal et al. (2002) identified a cooling trend over the last 10,000 years. Rimbu et al. (2003) suggested that this cooling trend is part of a regional SST pattern that resembles a modern SST-pattern, which is related to the Arctic Oscillation/North Atlantic Oscillation (AO/NAO) (e.g., Hurrell, 1995; Thompson and Wallace, 1998; Thompson et al., 2000). Analyzing global SST records, Lorenz and Lohmann (2004) show that the AO/NAO-like SST pattern in the North Atlantic realm is part of a global SST pattern showing a slight warming over almost the entire tropics and a cooling in the extra-tropics from 7 cal kyr BP to the present. Based on long-term transient climate simulations, Lorenz and Lohmann (2004) attributed these trends to solar insolation forcing associated with the Earth's precessional variation during 
the Holocene. The Holocene climate changes caused by the external forcing seem to be connected by climate modes (Rimbu et al., 2003, 2004; Lorenz et al., 2004). However, it is not well known how these climate modes induce inter-oceanic teleconnected climate variability during the Holocene.

The aim of this study is to investigate the spatial and temporal SST variations in the North Pacific and North Atlantic realms for the middle to late Holocene and the teleconnections between the two oceans. For this purpose, we used a set of North Pacific and North Atlantic alkenone-derived SST records covering the last 7000 years. The information in this data set is combined with the data analysis of a coupled atmosphere-ocean general circulation model (AOGCM) simulation. This will provide useful information on the dominant modes of climate variability in the North Pacific and the North Atlantic as well as on a common climate mode that the two oceans share.

The paper is organized as follows. Data and methods are described in Section 2. The main results follow in Section 3 with the SST trends and related spatial pattern in the Northern Hemisphere and with the Pacific-Atlantic teleconnections inferred from a control integration with a coupled AOGCM. Possible underlying mechanisms and summary and main conclusions are presented in Sections 4 and 5, respectively.

\section{Data and methods}

The inspection of Holocene climate trends is based on the statistical analysis of alkenone-derived SST records from the North Atlantic and North Pacific realms and of data from a control integration of a coupled atmosphere-ocean-sea ice model.

In this study, four new SST records and 32 published records compiled from the literature (Table 1) covering North Pacific and North Atlantic regions were analysed. In order to avoid potential biases due to using different SST proxies, the paleotemperature estimates of all sediment cores were based solely on the alkenone method, converting the abundance ratios of long-chain unsaturated alkenones with two to three double bounds into annual mean SST (e.g., Brassell et al., 1986; Prahl et al., 1988; Müller et al., 1998). The alkenone SST proxy has been internationally calibrated and standardized amongst 24 laboratories worldwide (Rosell-Melé et al., 2001). The error for alkenone temperature estimates is in the order of 0.5 and $1.5^{\circ} \mathrm{C}$, for the calibration with culture samples (Prahl and Wakeham, 1987) and surface sediments (Müller et al., 1998), respectively. Analytical precision for each record considered here, however, was much better than the calibration errors reported by Prahl and Wakeham (1987) and Müller et al. (1998) (Table 1). Although different alkenone unsaturation indices $\left(\mathrm{U}_{37}^{\mathrm{K}}\right.$ or $\left.\mathrm{U}_{37}^{\mathrm{K} \prime}\right)$ and calibrations were applied for each alkenone SST record (Table 1), it does not affect the comparison of relative SST changes. The core chronologies have been described in previous studies (Table 1). All alkenone SST records compiled in this study will be archived in the WDC-MARE/PANGAEA data base (http://www.pangaea.de/Projects/GHOST, Kim and Schneider, 2004).

In order to identify coherent temporal and spatial variations in the Holocene SST data set, different statistical methods were used. At first, the linear regression analysis for each individual record was applied in order to calculate the linear trend. Then, the spatial distribution of the SST variability was investigated separately for the North Pacific and North Atlantic regions, using an Empirical Orthogonal Function (EOF) analysis (von Storch and Zwiers, 1999). The SST time series were reduced into spatially coherent orthogonal eigenvectors. These eigenvectors, together with their corresponding time coefficients (Principal Component, PC) and eigenvalues (a measure of the variance described by each eigenvector) are referred to in our study as modes of SST variability. The EOF method also served as a data-filtering procedure to smooth the noise and uncertainties in the age models of the individual SST records.

The temporal patterns of the time coefficients of the dominant modes of alkenone SST variability were investigated using the Singular Spectrum Analysis (SSA) (Ghil et al., 2002). The SSA is designed to decompose a short and noisy time series into three statistically independent components: trends, oscillatory patterns, and noise. The trends do not need to be linear and the oscillations can be amplitude and phase modulated (Ghil et al., 2002). In our analysis all time components with a time scale longer than $3 \mathrm{kyr}$ (i.e. the size of the window) are referred to as trends while the time components with time scales smaller than $3 \mathrm{kyr}$ are referred to as centennial to millennial scale variations.

The EOF and SSA methods used here require that the SST values from different records are available for identical time resolution. Here, mean SST values in 100year time resolution were derived using linear interpolation. The SST anomalies against the SST mean over the considered period were calculated for each record and normalized with the corresponding standard deviation. The normalized time series were combined to obtain two separate space-time SST data sets, one for the North Pacific realm and the other for the North Atlantic realm.

In addition to the alkenone SST data, we employed the analysis from a 3000 year control simulation of the pre-industrial era with the ECHO-G coupled atmosphere-ocean model (Lorenz and Lohmann, 2004). The ECHO-G consists of the ECHAM-4 atmospheric general circulation model, which is coupled through the OASIS program with the HOPE ocean circulation 
Table 1

Core locations and information on the chronology, alkenone index, alkenone calibration, and analytical reproducibility for each SST record discussed in this paper

\begin{tabular}{|c|c|c|c|c|c|c|c|c|c|c|c|c|}
\hline No. & Core name & Lat. & Long. & $\begin{array}{l}\text { Water depth } \\
(\mathrm{m})\end{array}$ & Dating & $\begin{array}{l}14 \mathrm{C} \text { dating no. } \\
\text { used for age } \\
\text { model }\end{array}$ & $\begin{array}{l}\text { Mean sample } \\
\text { interval (min.- } \\
\text { max. })(\mathrm{cm})\end{array}$ & $\begin{array}{l}\text { Meantime } \\
\text { resolution (min.- } \\
\text { max.) (yr) }\end{array}$ & $\begin{array}{l}\text { Alkenone } \\
\text { index }\end{array}$ & $\begin{array}{l}\text { Alkenone } \\
\text { calibration }\end{array}$ & $\begin{array}{l}\text { Reproducibility } \\
\left({ }^{\circ} \mathrm{C}\right)\end{array}$ & Reference \\
\hline \multicolumn{13}{|c|}{ New data from this study } \\
\hline 2 & SSDP-I02 & 34.953 & 128.881 & 40 & AMS14C & 3 & $\sim 13(1-35)$ & $\sim 61(5-190)$ & UK'37 & $\begin{array}{l}\text { Prahl et al. } \\
\text { (1988) }\end{array}$ & $0.1( \pm l \sigma)$ & This study \\
\hline 19 & GeoB 5901-2 & 36.380 & -7.071 & 574 & AMS14C & 13 & $\sim 1(1-2)$ & $\sim 80(35-317)$ & UK'37 & $\begin{array}{l}\text { Prahl et al. } \\
\text { (1988) }\end{array}$ & $0.3( \pm l \sigma)$ & This study \\
\hline 35 & $74 \mathrm{KL}$ & 14.321 & 57.347 & 3212 & AMS14C & 3 & $\sim 3(2.5-5)$ & $\sim 281(208-722)$ & $\mathrm{UK}^{\prime} 37$ & $\begin{array}{l}\text { Prahl et al. } \\
\text { (1988) }\end{array}$ & $0.2( \pm 1 \sigma)$ & This study; Sirocko et al. (1993) \\
\hline 36 & TY93-905 & 11.067 & 51.950 & 1567 & AMS14C & 4 & 5 & $\sim 216(140-273)$ & $\mathrm{UK}^{\prime} 37$ & $\begin{array}{l}\text { Prahl et al. } \\
\text { (1988) }\end{array}$ & $0.3( \pm 1 \sigma)$ & This study \\
\hline \multicolumn{13}{|c|}{$\begin{array}{l}\text { Data from literature } \\
\text { North Pacific Realm }\end{array}$} \\
\hline 1 & GGC15 & 48.168 & 151.337 & 1980 & AMS $14 \mathrm{C}$ & 2 & 5 & $\sim 1058(920-1200)$ & $\mathrm{UK}^{\prime} 37$ & $\begin{array}{l}\text { Müller et al. } \\
\text { (1998) }\end{array}$ & $\begin{array}{l}0.025 \mathrm{UK}^{\prime} 37 \\
( \pm 1 \sigma)\end{array}$ & $\begin{array}{l}\text { Keigwin (1998) and Ternois et } \\
\text { al. (2000) }\end{array}$ \\
\hline 3 & ST.14 & 32.668 & 138.455 & 3252 & AMS 14C & 2 & $\sim 6(0.8-19.2)$ & $\sim 660(116-910)$ & UK'37 & $\begin{array}{l}\text { Prahl et al. } \\
\text { (1988) }\end{array}$ & - & Sawada and Handa (1998) \\
\hline 4 & ST.19 & 31.095 & 138.665 & 3336 & AMS $14 \mathrm{C}$ & 1 & $\sim 10(7.2-28.8)$ & $\sim 883(369-1090)$ & $\mathrm{UK}^{\prime} 37$ & $\begin{array}{l}\text { Prahl et al. } \\
\text { (1988) }\end{array}$ & - & Sawada and Handa (1998) \\
\hline 5 & $17940-2$ & 20.117 & 117.383 & 1727 & AMS $14 \mathrm{C}$ & 10 & $\sim 8(4-13)$ & $\sim 153(70-275)$ & $\mathrm{UK}^{\prime} 37$ & $\begin{array}{l}\text { Müller et al. } \\
\text { (1998) }\end{array}$ & $0.15( \pm 1 \sigma)$ & $\begin{array}{l}\text { Pelejero et al. (1999a) and Wang } \\
\text { et al. (1999) }\end{array}$ \\
\hline 6 & SCS90-36 & 17.995 & 111.494 & 2050 & AMS $14 \mathrm{C}$ & 1 & $\sim 3(1-5)$ & $\sim 800(255-1274)$ & $\mathrm{UK}^{\prime} 37$ & $\begin{array}{l}\text { Prahl et al. } \\
\text { (1988) }\end{array}$ & - & Huang et al. (1997) \\
\hline 7 & $18252-3$ & 9.233 & 109.383 & 1273 & AMS $14 \mathrm{C}$ & 0 & $\sim 14(10-30)$ & $\sim 587(427-1281)$ & UK'37 & $\begin{array}{l}\text { Pelejero and } \\
\text { Grimalt (1997) }\end{array}$ & $02< \pm 1 \sigma)$ & Kienast and McKay (2001) \\
\hline 8 & 17964 & 6.158 & 112.213 & 1556 & AMS $14 \mathrm{C}$ & 2 & $\sim 19(9-20)$ & $\sim 712(353-784)$ & $\mathrm{UK}^{\prime} 37$ & $\begin{array}{l}\text { Müller et al. } \\
\text { (1998) }\end{array}$ & $0.15( \pm 1 \sigma)$ & $\begin{array}{l}\text { Pelejero et al. (1999a, b) and } \\
\text { Wang et al. }(19990\end{array}$ \\
\hline 9 & JT96-0909pc & 48.912 & -126.890 & 920 & AMS $14 \mathrm{C}$ & 0 & $\sim 2(0.5-4)$ & $\sim 406$ (90-723) & $\mathrm{UK}^{\prime} 37$ & $\begin{array}{l}\text { Müller et al. } \\
\text { (1998) }\end{array}$ & $0.3( \pm 1 \sigma)$ & Kienast and McKay (2001) \\
\hline 10 & ODP 1019C & 41.682 & -124.930 & 980 & $\begin{array}{l}\text { AMS } 14 C, \\
\text { isotope } \\
\text { stratigraphy a }\end{array}$ & 3 & $\sim 5(4-11)$ & $\sim 132(85-289)$ & $\mathrm{UK}^{\prime} 37$ & $\begin{array}{l}\text { Prahl et al. } \\
\text { (1988) }\end{array}$ & $015( \pm 1 \sigma)$ & Barron et al. (2003) \\
\hline 11 & ODP 1017E & 34.535 & -121.107 & 955 & AMS $14 \mathrm{C}$ & 0 & $\sim 8(2.9-17.2)$ & $\sim 363(129-793)$ & $\mathrm{UK}^{\prime} 37$ & $\begin{array}{l}\text { Prahl et al. } \\
\text { (1988) }\end{array}$ & $\begin{array}{l}0.005 \mathrm{UK}^{\prime} 37 \\
( \pm 1 \sigma)\end{array}$ & $\begin{array}{l}\text { Kennett et al. (2000) and } \\
\text { Ostertag-Henning and Stax } \\
(2000)\end{array}$ \\
\hline 12 & LAPAZ21P & 22.990 & -109.47 & 624 & $\begin{array}{l}\text { SPECMAP } \\
\text { chronology }\end{array}$ & - & $\sim 5(4-5)$ & $\sim 769(633-792)$ & UK'37 & $\begin{array}{l}\text { Prahl et al. } \\
\text { (1988) }\end{array}$ & $0.15( \pm 1 \sigma)$ & Herbert et al. (2001) \\
\hline \multicolumn{13}{|c|}{ North Atlantic and Indian Ocean Realm } \\
\hline 13 & M23258-2 & 74.995 & 13.970 & 1768 & AMS14C & 5 & $\sim 3(2-6)$ & $\sim 196(119-349)$ & UK37 & $\begin{array}{l}\text { Rosell-Melé et } \\
\text { al. (1995) }\end{array}$ & - & $\begin{array}{l}\text { Marchal et al. (2002) and } \\
\text { Sarnthein et al. (2003) }\end{array}$ \\
\hline 14 & MD952011 & 66.967 & 7.633 & 1048 & AMS14C & 9 & $\sim 4(1-15)$ & $\sim 58(4-245)$ & UK37 & $\begin{array}{l}\text { Prahl and } \\
\text { Wakeham } \\
(1987)\end{array}$ & $0.15( \pm 1 \sigma)$ & Calvo et al. (2002) \\
\hline 15 & MD952015 & 58.762 & -25.958 & 2630 & AMS14C & $?$ & $\sim 5(5-10)$ & $\sim 101(75-201)$ & $\mathrm{UK}^{\prime} 37$ & $\begin{array}{l}\text { Müller et al. } \\
\text { (1998) }\end{array}$ & - & Marchal et al. (2002) \\
\hline 16 & IOW225514 & 57.838 & 8.704 & 420 & AMS $14 \mathrm{C}$ & 6 & $\sim 5(1-5)$ & $\sim 68(8-271)$ & $\mathrm{UK}^{\prime} 37$ & $\begin{array}{l}\text { Müller et al. } \\
\text { (1998) }\end{array}$ & - & Emeis et al. (2003) \\
\hline 17 & IOW225517 & 57.667 & 7.091 & 293 & AMS14C & 6 & $\sim 5(1-10)$ & $\sim 94(18-179)$ & UK'37 & $\begin{array}{l}\text { Müller et al. } \\
\text { (1998) }\end{array}$ & - & Emeis et al. (2003) \\
\hline IS & SU81-18 & 37.767 & -10.183 & 3135 & AMS14C & 5 & $\sim 10(9-10)$ & $\sim 736(568-837)$ & UK'37 & $\begin{array}{l}\text { Prahl et al. } \\
\text { (1988) }\end{array}$ & 0.3 & Bard et al. (2000) \\
\hline 20 & M39-008 & 36.382 & -7.077 & 576 & AMS $14 \mathrm{C}$ & 4 & 5 & $\sim 545(178-1265)$ & $\mathrm{UK}^{\prime} 37$ & $\begin{array}{l}\text { Müller et al. } \\
\text { (1998) }\end{array}$ & $0.15( \pm 1 \sigma)$ & Cacho et al. (2001) \\
\hline 21 & MD952043 & 36.143 & -2.622 & 1841 & AMS14C & 4 & $\sim 5(2-10)$ & $\sim 133(66-223)$ & $\mathrm{UK}^{\prime} 37$ & Müller et al. & $0.15( \pm 1 \sigma)$ & Cacho et al. (1999) \\
\hline
\end{tabular}




\begin{tabular}{|c|c|c|c|c|c|c|c|c|c|c|c|c|}
\hline No. & Core name & Lat. & Long. & $\begin{array}{l}\text { Water depth } \\
(\mathrm{m})\end{array}$ & Dating & $\begin{array}{l}14 \mathrm{C} \text { dating no. } \\
\text { used for age } \\
\text { model }\end{array}$ & $\begin{array}{l}\text { Mean sample } \\
\text { interval (min.- } \\
\text { max.) }(\mathrm{cm})\end{array}$ & $\begin{array}{l}\text { Meantime } \\
\text { resolution (min.- } \\
\text { max.) (yr) }\end{array}$ & $\begin{array}{l}\text { Alkenone } \\
\text { index }\end{array}$ & $\begin{array}{l}\text { Alkenone } \\
\text { calibration }\end{array}$ & $\begin{array}{l}\text { Reproducibility } \\
\left({ }^{\circ} \mathrm{C}\right)\end{array}$ & Reference \\
\hline 22 & BS79-38 & 38.412 & 13.577 & 1489 & $\begin{array}{l}\text { Isotope } \\
\text { stratigraphy }{ }^{c}\end{array}$ & - & $\sim 7(5-10)$ & $\sim 329(216-520)$ & UK'37 & $\begin{array}{l}\text { (1998) } \\
\text { Müller et al. } \\
\text { (1998) }\end{array}$ & $0.15( \pm 1 \sigma)$ & Cacho et al. (2001) \\
\hline 23 & $\begin{array}{l}\text { M40-4-SL 78/ } \\
\text { 78MUC8 }\end{array}$ & 37.036 & 13.19 & 470 & $\begin{array}{l}\text { AMS 14C, } \\
\text { Isotope } \\
\text { stratigraphy }\end{array}$ & 1 & $\sim 3(1-12)$ & $\sim 124(33-498)$ & UK'37 & $\begin{array}{l}\text { Müller et al. } \\
\text { (1998) }\end{array}$ & - & $\begin{array}{l}\text { Emeis and Dawson (2003) and } \\
\text { Emeis (unpublished) }\end{array}$ \\
\hline 24 & AD91-17 & 40.870 & 18.636 & 844 & $\begin{array}{l}\text { AMS } 14 \mathrm{C}, \\
\text { isotope } \\
\text { stratigraphy }\end{array}$ & 3 & $\sim 4(2-6)$ & $\sim 158(45-442)$ & $\mathrm{UK}^{\prime} 37$ & $\begin{array}{l}\text { Müller et al. } \\
\text { (1998) }\end{array}$ & - & Giunta et al. (2001) \\
\hline 25 & RL11 & 36.746 & 17.718 & 3376 & AMS14C & 2 & $\sim 1(1-3)$ & $\sim 261(105-804)$ & UK'37 & $\begin{array}{l}\text { Müller et al. } \\
\text { (1998) }\end{array}$ & - & Emeis et al. (2000) \\
\hline 26 & M44-KL71 & 40.842 & 27.763 & 566 & AMS14C & 0 & $\sim 4(2-6)$ & $\sim 324(157-619)$ & UK'37 & $\begin{array}{l}\text { Müller et al. } \\
\text { (1998) }\end{array}$ & - & Sperling et al. (2003) \\
\hline 27 & ODP $658 \mathrm{C}$ & 20.750 & -18.583 & 2263 & AMSI4C & 5 & $\sim 2(2-11)$ & $\sim 100(30-370)$ & $\mathrm{UK}^{\prime} 37$ & $\begin{array}{l}\text { Prahl et al. } \\
\text { (1988) }\end{array}$ & - & $\begin{array}{l}\text { Zhao et al. (1995) and } \\
\text { deMenocal et al. (2000) }\end{array}$ \\
\hline 28 & BOFS $31 \mathrm{~K}$ & 19.000 & -20.167 & 3300 & $\begin{array}{l}\text { Isotope } \\
\text { stratigraphy }{ }^{\mathrm{f}}\end{array}$ & 0 & 2 & 〜909 (900-910) & $\mathrm{UK}^{\prime} 37$ & $\begin{array}{l}\text { Prahl et al. } \\
\text { (1988) }\end{array}$ & $0.017 \mathrm{UK}^{\prime} 37$ & $\begin{array}{l}\text { Zhao et al. (1995) and Chapman } \\
\text { et al. (1996) }\end{array}$ \\
\hline 29 & ODP $1002 \mathrm{C}$ & 10.712 & -65.17 & 893 & $\begin{array}{l}\text { SPECMAP } \\
\text { chronology }\end{array}$ & & $\sim 23(18-40)$ & $\sim 503(400-890)$ & $\mathrm{UK}^{\prime} 37$ & $\begin{array}{l}\text { Prahl et al. } \\
\text { (1988) }\end{array}$ & 0.3 & $\begin{array}{l}\text { Herbert and Schuffert (2000) } \\
\text { and Peterson et al. (2000) }\end{array}$ \\
\hline 30 & M35003-4 & 12.083 & -61.250 & 1299 & AMS14C & 3 & 5 & $\sim 291(256-297)$ & UK'37 & $\begin{array}{l}\text { Müller et al. } \\
\text { (1998) }\end{array}$ & $0.3( \pm 1 \sigma)$ & Rühlemann et al. (1999) \\
\hline 31 & ODP 967D & 34.071 & 32.726 & 2551 & $\begin{array}{l}\text { SPECMAP } \\
\text { chronology }\end{array}$ & - & $\sim 5(1-15)$ & 〜309 (89-793) & UK'37 & $\begin{array}{l}\text { Müller et al. } \\
\text { (1998) }\end{array}$ & & Emeis et al. (2000) \\
\hline 32 & GeoB 5844-2 & 27.714 & 34.682 & 963 & AMS 14C & 5 & 2 & $\sim 307(215-364)$ & UK'37 & $\begin{array}{l}\text { Prahl et al. } \\
\text { (1988) }\end{array}$ & $0.6( \pm 1 \sigma)$ & Arz et al. (2003) \\
\hline 33 & $\begin{array}{l}\text { SO90-39KG/ } \\
56 \mathrm{KA}\end{array}$ & 24.834 & 65.917 & 695 & $\begin{array}{l}\text { Varve } \\
\text { chronology, } \\
\text { AMS and } \\
\text { conventional } \\
14 \mathrm{C}\end{array}$ & 19 & $\sim 2(1-15)$ & $\sim 20(0.2-86)$ & UK'37 & $\begin{array}{l}\text { Sonzogni et al. } \\
\text { (1997) }\end{array}$ & $0.3( \pm 1 \sigma)$ & $\begin{array}{l}\text { von Rad et al. (1999) and } \\
\text { Doose-Rolinski et al. (2001) }\end{array}$ \\
\hline 34 & SO93-126KL & 19.973 & 90.034 & 1253 & $\begin{array}{l}\text { SPECMAP } \\
\text { chronology }\end{array}$ & - & $\sim 5(3-6)$ & $\sim 654(364-1097)$ & UK'37 & $\begin{array}{l}\text { Sonzogni et al. } \\
\text { (1997) }\end{array}$ & & Kudrass et al. (2001) \\
\hline
\end{tabular}

$\mathrm{UK}^{\prime} 37=\mathrm{C} 37: 2 /(\mathrm{C} 37: 2+\mathrm{C} 37: 3)$ according to Prahl and Wakeham (1987); UK37 $=(\mathrm{C} 37: 2-\mathrm{C} 37 ; 4) /(\mathrm{C} 37: 2+\mathrm{C} 37: 3+\mathrm{C} 37: 4)$ according to Brassell et al. (1986); Prahl and Wakeham (1987): T $\left({ }^{\circ} \mathrm{C}=(\mathrm{UK} 37+0.11) / 0.04\right.$; Müller et al. (1998): $T\left({ }^{\circ} \mathrm{C}\right)=\left(\mathrm{UK}^{\prime} 37-0.044\right) / 0.033$; Prahl et al. $(1988)$ : $\mathrm{T}\left({ }^{\circ} \mathrm{C}\right)=\left(\mathrm{UK}^{\prime} 37-0.039\right) / 0.034$; Sonzogni et al. $(1997)$ : $T\left({ }^{\circ} \mathrm{C}\right)=\left(\mathrm{UK}{ }^{\prime} 37-0.317\right) / 0.023$; Pelejero and Grimalt (1997): $T\left({ }^{\circ} \mathrm{C}\right)=\left(\mathrm{UK}^{\prime} 37-0.092\right) / 0.031$; Rosell-Melé et al. $(1995): T\left({ }^{\circ} \mathrm{C}\right)=(\mathrm{UK} 37-0.093) / 9.03$.

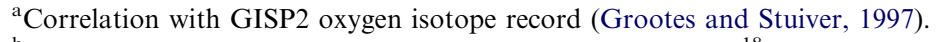

${ }^{b}$ The age model was obtained by correlation of the benthic $\delta^{18} \mathrm{O}$ record with the composite records of Shackleton (2000).

${ }^{\mathrm{c}}$ The age model was obtained by correlation of the planktonic $\delta^{18} \mathrm{O}$ records with those reported from Capotondi el al. (1999).

${ }^{\mathrm{d} C}$ Comparison with ODP 963 data from the same location (Sprovieri et al., pers.comm.)

${ }^{\mathrm{e}}$ The age model of the core AD91-17 is based on AMS 14C, planktonic isotopic record from Capotondi et al. (1999) and the correlation with MD90-917 planktonic isotopic record (Siani et al., 2001).

${ }^{\mathrm{f}}$ The chronology was obtained by attributing ages to the bey stratigrahic events, which have been identified in other cores from the North Atlantic with detailed radiocarbon chronologies (Bard et al., 1989).

${ }^{\mathrm{g}}$ The age model was obtained by correlation of the planktonic $\delta^{18} \mathrm{O}$ records with the standard SPECMAP composite record from Imbrie et al. (1984).

${ }^{\mathrm{h}}$ The age model was obtained by correlation of the planktonic $\delta^{18} \mathrm{O}$ records with Ihe standard SPECMAP composite record from Martinson et al. (1987). 
model including a dynamic sea-ice model (Legutke and Voss, 1999). It was forced with present boundary conditions such as solar radiation, sea and continental ice, vegetation, and distribution of land. The atmospheric greenhouse gas concentrations were prescribed at pre-industrial values $\left(280 \mathrm{ppm} \mathrm{CO}_{2}, 700 \mathrm{ppb} \mathrm{CH}_{4}\right.$, and $265 \mathrm{ppb} \mathrm{N}_{2} \mathrm{O}$ ) (Lorenz and Lohmann, 2004). The last 2300 years of this experiment with constant preindustrial conditions provide the basis for the statistical analysis of spatial and temporal patterns on centennial time scales. The surface temperature data consist of water temperatures over open water whereas temperatures of the overlying sea ice or snow layer over sea ice covered areas are taken into account. Prior to the statistical analysis, we calculated the 50-year averages. The averaged data were linearly detrended.

\section{Results}

\subsection{SST trends and related spatial patterns in the North Pacific realm}

In general, except for two sites, the alkenone-derived SST records from the North Pacific realm show a warming or no pronounced Holocene temperature trend (temperature plateau) from $7 \mathrm{cal} \mathrm{kyr} \mathrm{BP}$ to the present (Fig. 1a). The magnitudes of cooling and warming
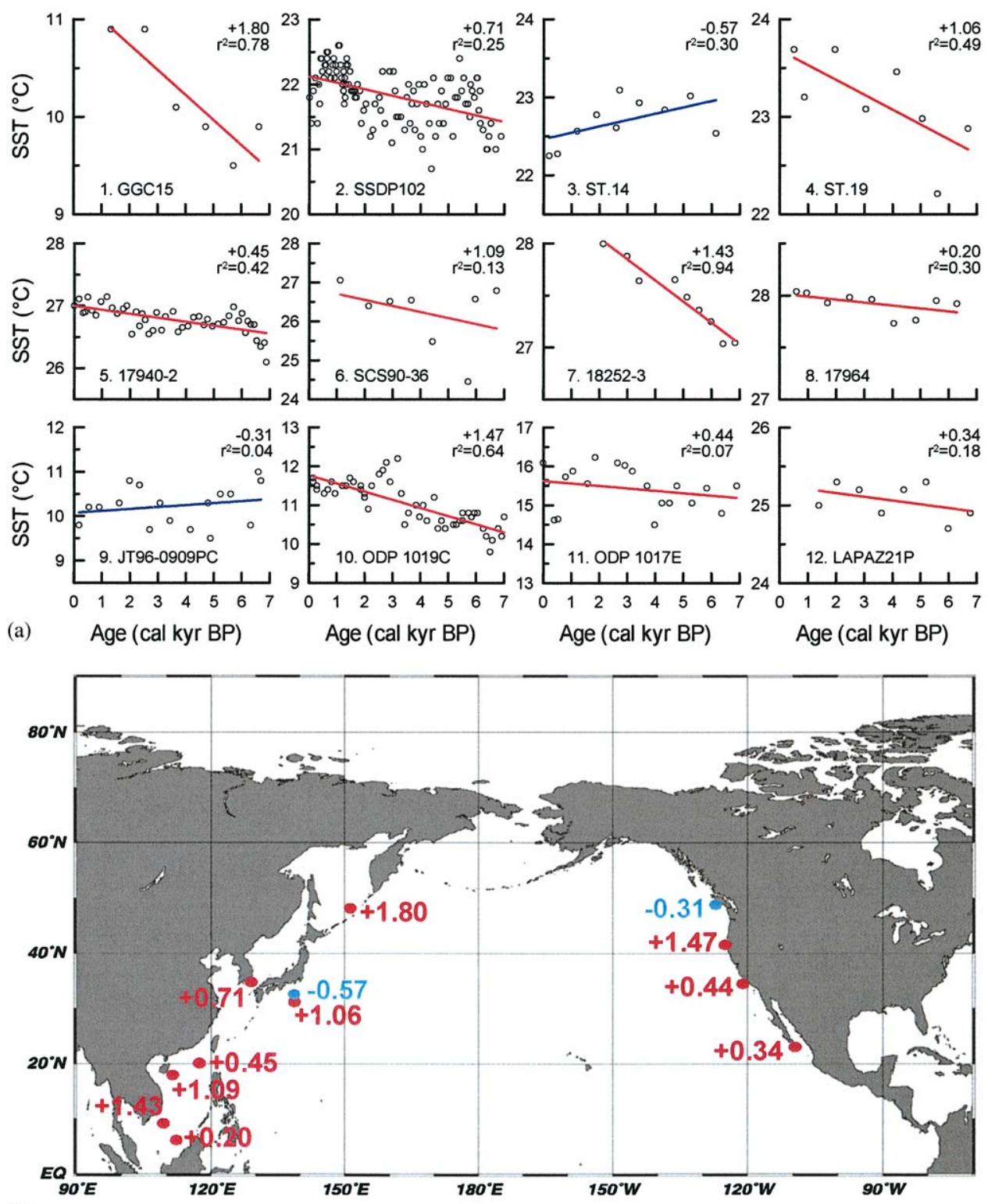

(b)

Fig. 1. (a) Data points (open circles) and linear trends of alkenone SST reconstructions from the North Pacific realm. The magnitudes of SST change over the last 7000 years $\left({ }^{\circ} \mathrm{C} / 7 \mathrm{kyr}\right)$ are indicated in the upper right corner and the core names are given in the lower left corner of each panel. The numbers refer to Table 1. $r$ is the correlation coefficient. (b) The spatial distribution of the magnitude of SST change $\left({ }^{\circ} \mathrm{C} / 7 \mathrm{kyr}\right)$ as shown in (a). 
varied between -0.57 and $-0.31{ }^{\circ} \mathrm{C} / 7 \mathrm{kyr}$ and +0.20 and $+1.80^{\circ} \mathrm{C} / 7 \mathrm{kyr}$, respectively. The SST records sometimes show very different trends, even within small distance and across oceanic fronts in the eastern and western boundary current systems (Fig. 1b).

The first EOF describes about $42 \%$ of the field variance (Fig. 2a). The sign of leading EOF of SST variability in the North Pacific realm indicates a spatial pattern similar to that of linear trend coefficients except for one site in the northeastern Pacific (Fig. 1a). The cooling trend in the northeastern Pacific is not captured by the first EOF. The associated principal component (PC1) shows an increasing trend with an abrupt transition between 4 and 3 cal kyr BP (Fig. 2b). This indicates a clear large-scale warming pattern in the northeastern Pacific over the last 7000 years. In the northwestern Pacific, the pattern also indicates a warming trend except for one site off central Japan, which shows a cooling from $7 \mathrm{cal}$ kyr BP to the present.

In order to identify the temporal patterns of North Pacific SST variability over the last 7000 years, we decomposed the PC1 associated to the first EOF of SST variability from this region (Fig. $2 \mathrm{c}$ and $\mathrm{d}$ ), using the SSA. The reconstructed signal from the first two SSA components (i.e. trends) of the PC1, which describes $97 \%$ of the variance, captures the long-term transition from relatively cold conditions to relatively warm conditions over the last 7000 years (Fig. 2c). The reconstructed signal from the next six SSA components, which describes $3 \%$ of the variance, shows enhanced millennial scale variability (Fig. 2d).

\subsection{SST trends and related spatial patterns in the North Atlantic realm}

The alkenone-derived SST records from the North Atlantic realm show different linear trends over the last 7000 years (Fig. 3a). The magnitude of cooling or warming varied between -4.41 and $-0.04{ }^{\circ} \mathrm{C} / 7 \mathrm{kyr}$ or between +0.13 and $+2.44^{\circ} \mathrm{C} / 7 \mathrm{kyr}$, respectively. The zonal distributions of SST trends show east-west differences for the same latitudes (Fig. 3b). The northeastern Atlantic and the western Mediterranean Sea cooled while the eastern Mediterranean Sea, the northern Red Sea, the northern Arabian Sea, and the Gulf of Bengal experienced a warming (Fig. 3b).

The first EOF describes $43 \%$ of the field variance (Fig. 4a). The sign of leading EOF of SST variability in the North Atlantic realm indicates a spatial pattern similar to that of linear trend coefficients (Fig. 3b). The associated PC1 (Fig. 4b) emphasizes a strong linear trend, indicating a continuous cooling in the northeastern Atlantic and the western Mediterranean Sea contrary to a warming in the eastern Mediterranean Sea, the northern Red Sea, the northern Arabian Sea, and the Gulf of Bengal over the last 7000 years (Fig. 4a).
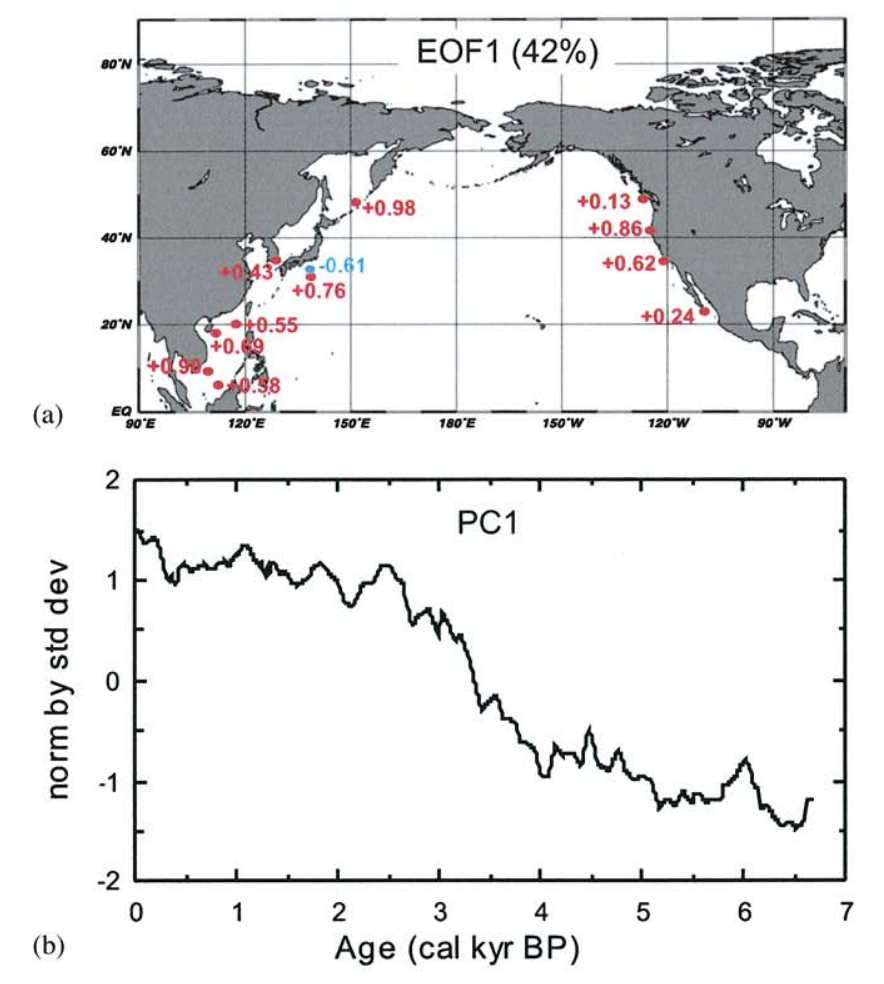

(b)

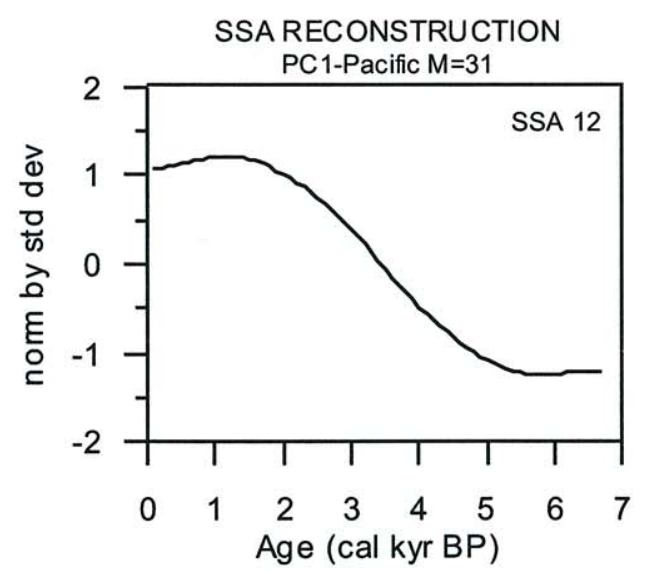

(c)

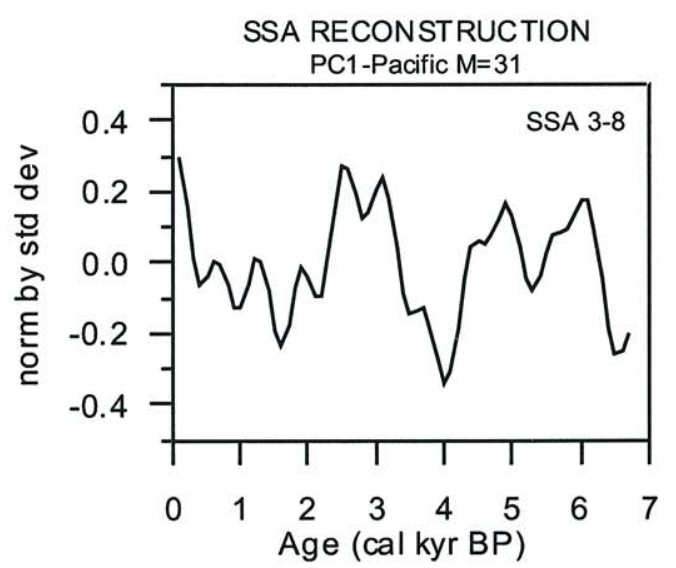

Fig. 2. (a) The first Empirical Orthogonal Function (EOF) of the North Pacific alkenone SST reconstructions and (b) its associated time coefficients (PC1) for the last 7000 years. (c) Reconstruction of the time coefficients of the first EOF of the North Pacific SST variability from the first two Singular Spectrum Analysis (SSA) components (i.e., trends) and (d) from the next six SSA components. $M=31$ indicates the length of the window in the SSA which is $3.1 \mathrm{kyr}$. 

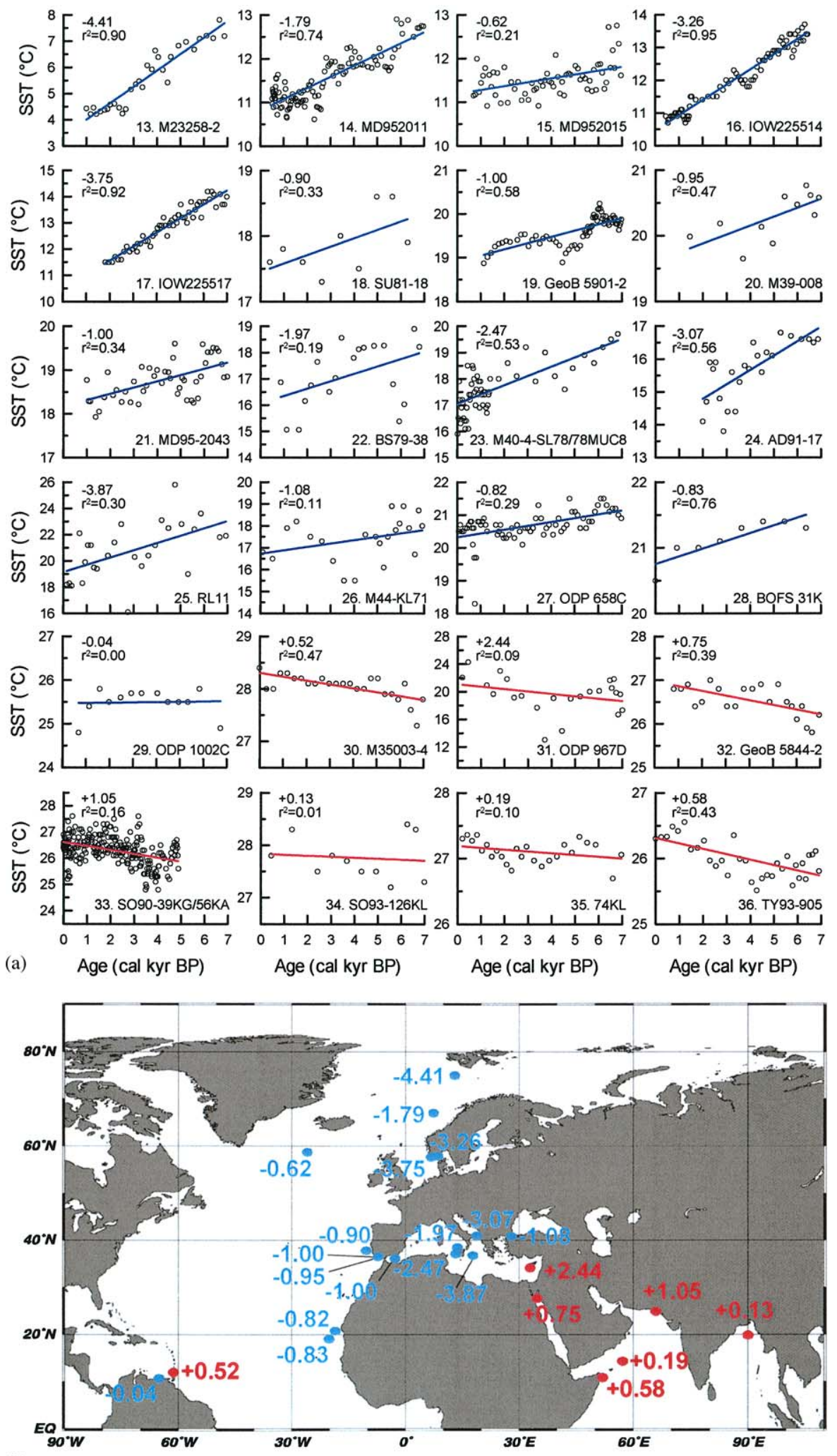

(b)

Fig. 3. (a) Data points (open circles) and linear trends of alkenone SST reconstructions from the North Atlantic realm. The magnitudes of SST change over the last 7000 years $\left({ }^{\circ} \mathrm{C} / 7 \mathrm{kyr}\right)$ are indicated in the upper right corner and the core names are given in the lower left corner of each panel. The numbers refer to Table 1. $r$ is the correlation coefficient. (b) The spatial distribution of the magnitude of SST change $\left({ }^{\circ} \mathrm{C} / 7 \mathrm{kyr}\right)$ as shown in (a). 
(a)
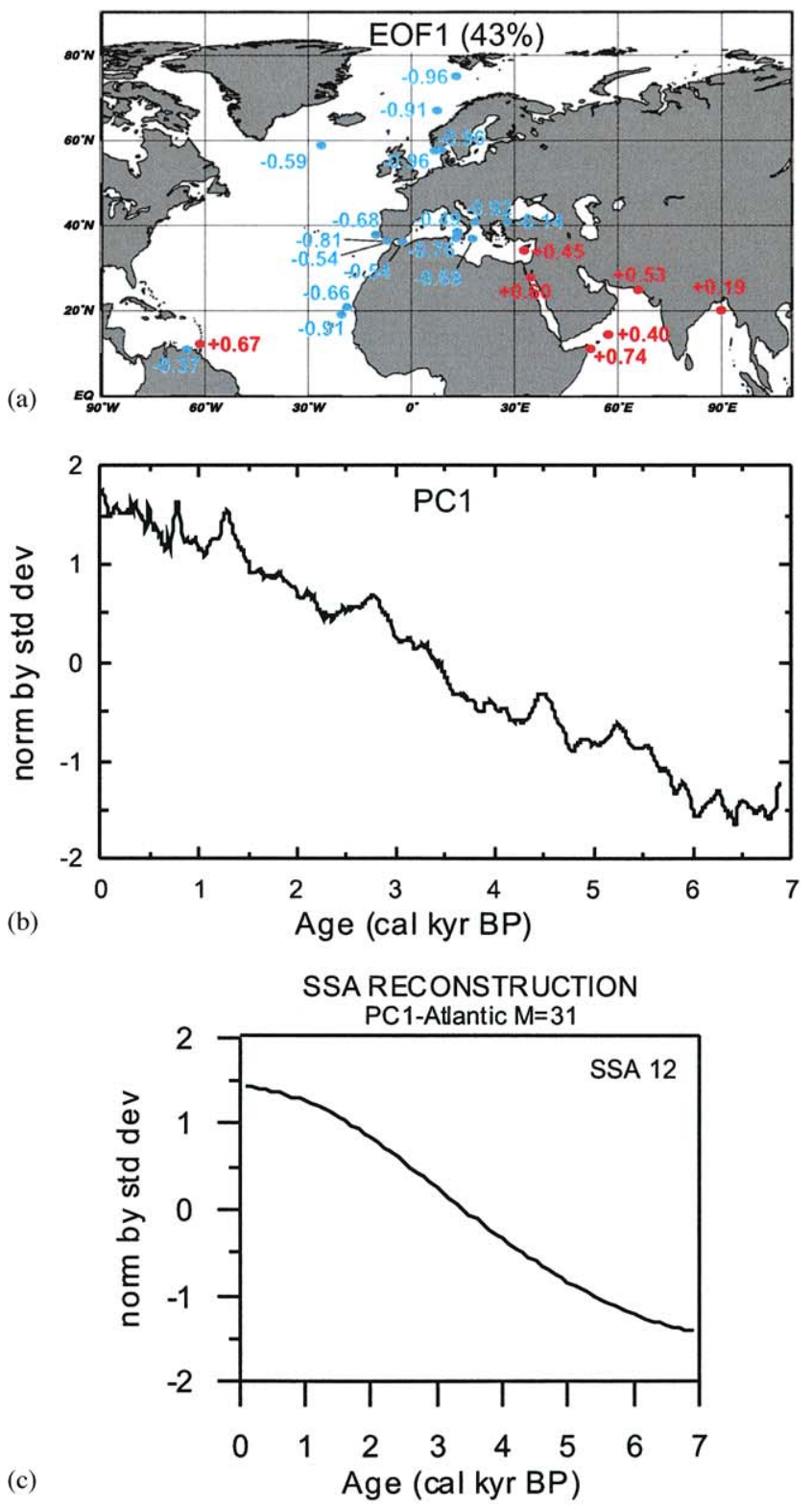

(c)

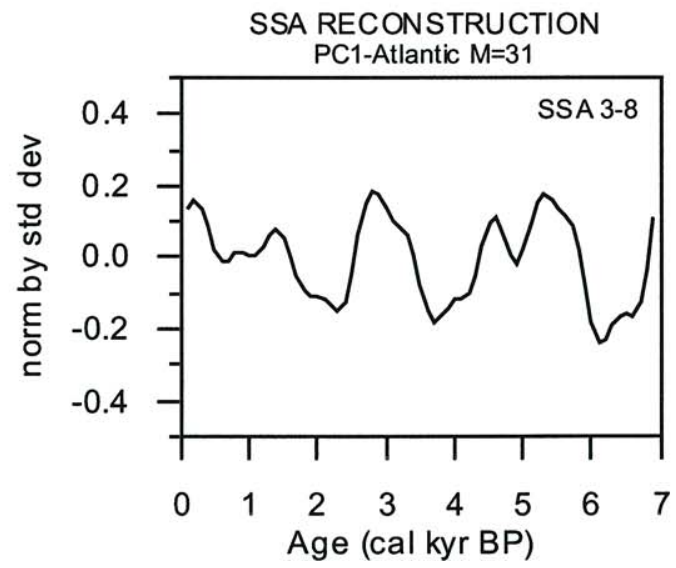

(d)

Fig. 4. (a) The first EOF of the North Atlantic alkenone SST reconstructions and (b) its associated time coefficients (PC1) for the last 7000 years. (c) Reconstruction of the time coefficients of the first EOF of the North Atlantic SST variability from the first two SSA components (i.e., trends) and (d) from the next six SSA components. $M=31$ indicates the length of the window in the SSA which is $3.1 \mathrm{kyr}$.
Interestingly, the $\mathrm{PC} 1$ for the North Atlantic realm does not indicate an abrupt shift at $4-3$ cal kyr BP, which is the case of the PC1 for the North Pacific realm.

In order to identify the temporal patterns of North Atlantic SST variability over the last 7000 years like in the North Pacific, we decomposed the PC1 associated to the first EOF of SST variability from this region (Figs. $4 \mathrm{c}$ and $\mathrm{d}$ ), using the SSA. The trend signal from the first two SSA components of the PC1, which describes $96 \%$ of the variance, captures the long-term transition over the last 7000 years (Fig. 4c). The reconstructed signal from the next six SSA components, which shows $4 \%$ of the variance, show enhanced millennial scale variability (Fig. 4d).

\subsection{Coupled atmosphere-ocean general circulation model experiment}

To better assess the North Pacific and North Atlantic SST spatial patterns derived from the analysis of the alkenone SST data, the centennial variability in the 2300 year long control integration of the ECHO-G model (Lorenz and Lohmann, 2004) was investigated. Noteworthy is that in this simulation the variability is generated only by internal processes while the alkenone SST variability is assumed to follow both internal and external forcing mechanisms.

Based on the spatial pattern of the North Pacific SST as derived from alkenone SST data (Fig. 2a), a northeastern Pacific surface temperature (ST) index was defined by ST anomalies from the 2300 year long simulation. The index was obtained by averaging the simulated STs over the area $140-110^{\circ} \mathrm{W}$ and $20-60^{\circ} \mathrm{N}$ and subtracting the mean value. In Fig. 5a, the time series of this index (red box in Fig. 5b) is represented. Over this region, the alkenone SST data indicate a clear warming trend from 7 cal kyr BP to the present (Fig. 2a). The correlation map between the northeastern Pacific ST index (Fig. 5a) and model STs over the entire Northern Hemisphere indicates that positive temperature anomalies in the northeastern Pacific are accompanied by negative temperature anomalies in the northeastern Atlantic (Fig. 5b).

Motivated by the distribution of the 7000 year cooling trend in alkenone SSTs from this region (Fig. 4a), a northeastern Atlantic ST index was defined by ST anomalies from the 2300 year long ST data (Fig. 6a). The index was obtained by averaging the simulated STs over the area $30^{\circ} \mathrm{W}-10^{\circ} \mathrm{E}$ and $30-70^{\circ} \mathrm{N}$ (red box in Fig. 6b) and subtracting the mean value. The correlation map between the northeastern Atlantic ST index and simulated Northern Hemisphere STs shows that a warming in the northeastern Atlantic accompanies a cooling in the northeastern Pacific (Fig. 6b). 

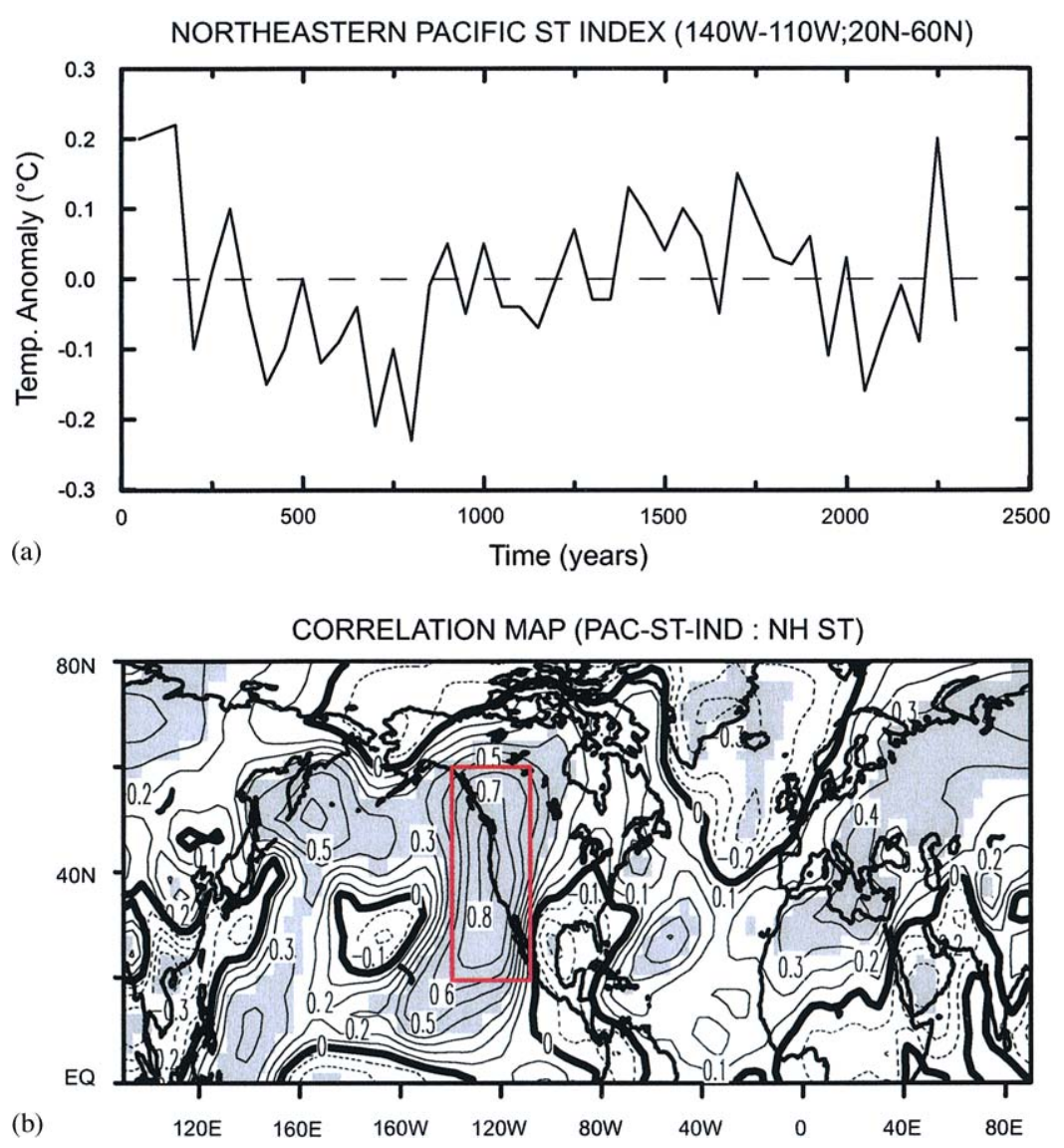

Fig. 5. (a) The time series of the northeastern Pacific surface temperature (ST) index. The index was obtained by averaging the simulated STs over the area $\left(140-110^{\circ} \mathrm{W}: 20-60^{\circ} \mathrm{N}\right)$ and subtracting the mean value. The 50-yr mean ST data were used for the analysis. (b) The correlation map of the ST index with Northern Hemisphere ST from the pre-industrial simulation of the ECHO-G coupled model. Shading indicates the areas with statistical significance of the correlations at the $95 \%$ confidence level based on a $t$-test. The red box shows the ST index area.

\section{Possible underlying mechanisms}

The correlation coefficient between the northeastern Pacific and northeastern Atlantic ST indices defined above is -0.25 (significant at $95 \%$ level). In order to identify atmospheric circulation patterns that may connect the northeastern Pacific and northeastern Atlantic SST variability at centennial time scales and that may also be related to the observed spatial distribution of positive and negative long-term SST trends as shown by the alkenone SST data, a third ST index was defined. It is the difference between the northeastern Pacific and northeastern Atlantic ST indices described above, where the mean value was subtracted (Fig. 7a). A high value of the ST index indicates a simultaneous warming in the northeastern Pacific and a cooling in the northeastern Atlantic.

Based on this ST index, a composite map of the Northern Hemisphere sea level pressure (SLP) was constructed (Fig. 7b). The SLP composite map consists of an average over those years when the values of the ST index are higher (lower) than 1 standard deviation. The
SLP composite map, which is the difference between the averaged SLP maps, indicates an SLP pattern which bears similarities of the Pacific North American (PNA) and NAO atmospheric circulation patterns. The PNA pattern represents a large-scale atmospheric teleconnection between the North Pacific and North America (Wallace and Gutzler, 1981). It is characterized by an atmospheric flow in which the west coast of North America is out of phase with the northeastern Pacific and southeastern United States. During the positive PNA phase, low SLP is centred over the North Pacific and high SLP over western North America. The NAO is the dominant mode of atmospheric behaviour in the North Atlantic. It is a large-scale seesaw in atmospheric mass between the polar low-pressure centre (Icelandic Low) and the subtropical high-pressure centre (Azores High). During the positive NAO, the Icelandic Low is deeper than normal and the Azores High is stronger than usual. The SLP composite map (Fig. 7b) shows the positive phase of the PNA in the North Pacific realm and the negative phase of the NAO in the North Atlantic realm. This suggests that the opposing SST 


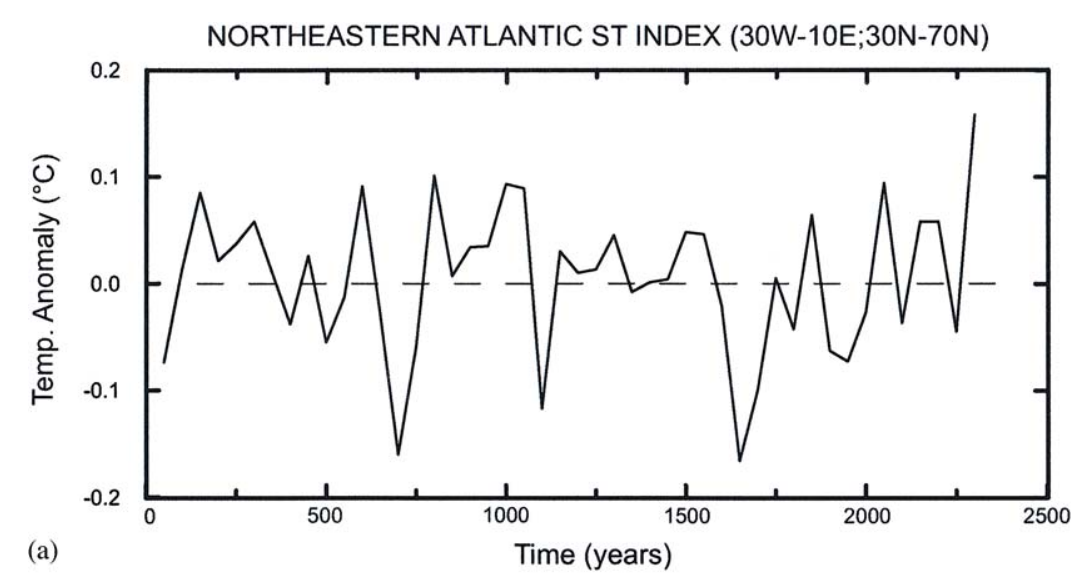

(a)

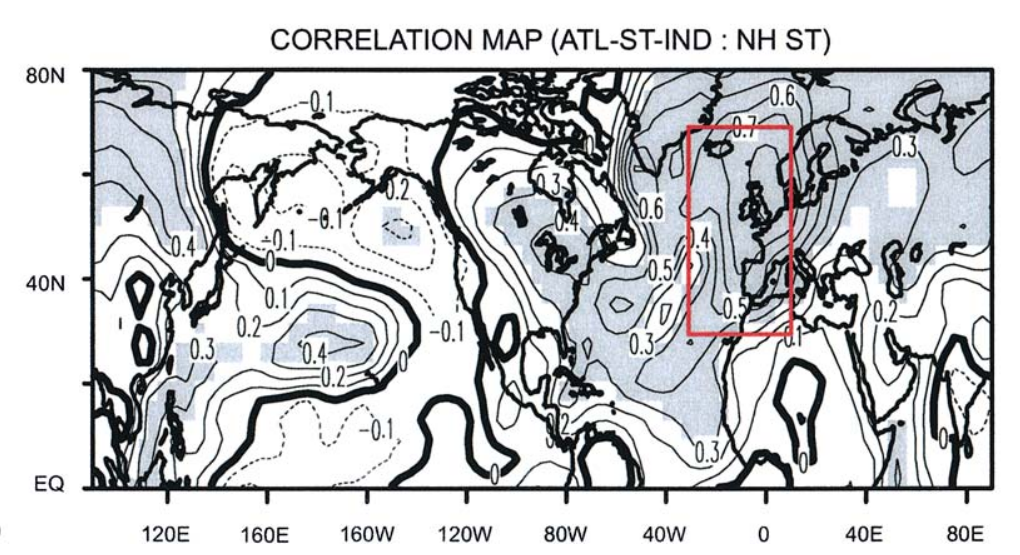

Fig. 6. (a) The time series of the northeastern Atlantic surface temperature (ST) index. The index was obtained by averaging the simulated STs over the area $\left(30^{\circ} \mathrm{W}-10^{\circ} \mathrm{E}: 30-70^{\circ} \mathrm{N}\right)$ and subtracting the mean value. The 50 -yr mean ST data were used for the analysis. (b) The correlation map of ST index with Northern Hemisphere ST from the 2300-year long simulation of ECHO-G coupled model. Shading indicates the areas with statistical significance of the correlations at the $95 \%$ confidence level based on a $t$-test. The red box shows the ST index area.

pattern between the northeastern Pacific and the northeastern Atlantic as seen in the alkenone SST data was probably caused by an interaction of the positive PNA and the negative NAO phases.

A composite map of the Northern Hemisphere ST (Fig. 7c) was also constructed based on the ST index. Like the SLP composite map, the ST composite map consists of an average over those years when the values of the ST index are higher (lower) than 1 standard deviation. The ST composite map, which is the difference between the averaged ST maps, shows a temperature distribution pattern which bears some resemblance of the Pacific-Decadal Oscillation (PDO) for the instrumental era (Mantua et al., 1997; Mantua and Hare, 2002). The PDO represents decadal changes in SST patterns in the North Pacific. A positive PDO phase equates to anomalously warm surface water in the equatorial Pacific and along the west coast of North America, but anomalously cool surface water in the west Pacific. The PDO atmospheric circulation anomalies extend through the depth of the troposphere and are well expressed as persistence in the PNA pattern described by Wallace and Gutzler (1981). The ST composite map (Fig. 7c) shows the positive PDO phase consistent with the positive PNA phase (Fig. 7b). The SST pattern in the North Atlantic realm (Fig. 7c) resembles the NAO-related SST pattern (e.g., Hurrell, 1995), showing an opposing pattern between the northeastern Atlantic and the eastern Mediterranean Sea and the northern Red Sea. The SST pattern in the ST composite map fits relatively well to the alkenonederived SST pattern in the northeastern Pacific and northeastern Atlantic realms (Figs. 2a and 4a).

In summary, the inverse SST pattern between the northeastern Pacific and the northeastern Atlantic in the model simulation is connected to an atmospheric circulation field that comprises the elements of the PNA pattern and the NAO in opposite phases. The similar SST seesaw observed in both the alkenone SST data and the simulated data suggests that the PNA and NAO-like atmospheric circulation pattern are also responsible for the inverse long-term SST trends between the northeastern Pacific and the northeastern Atlantic during the Holocene. 


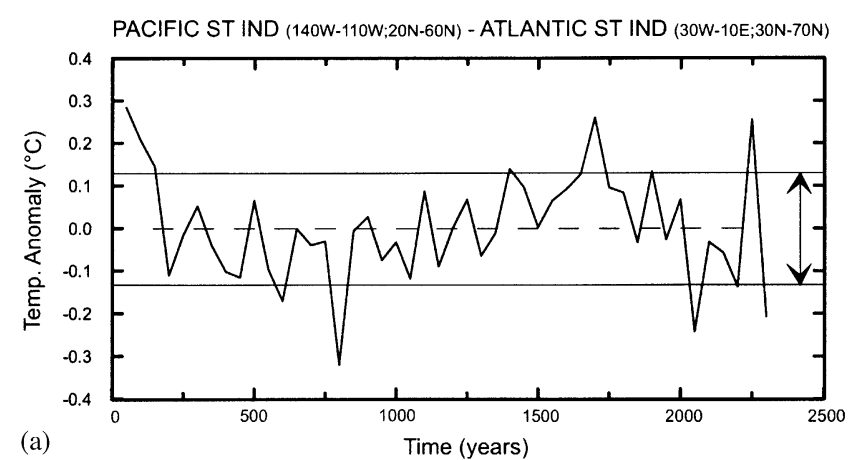

(a)

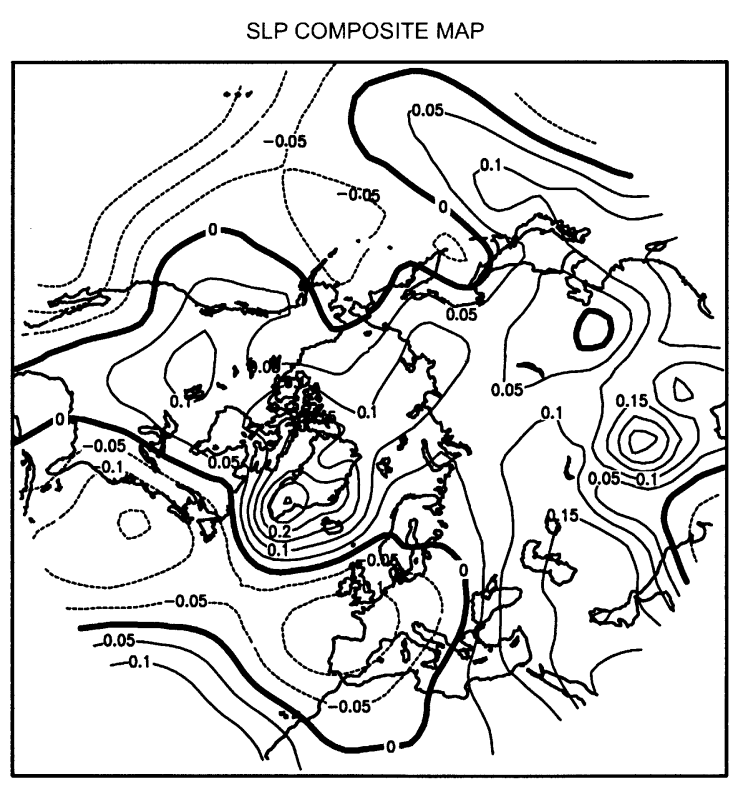

(b)

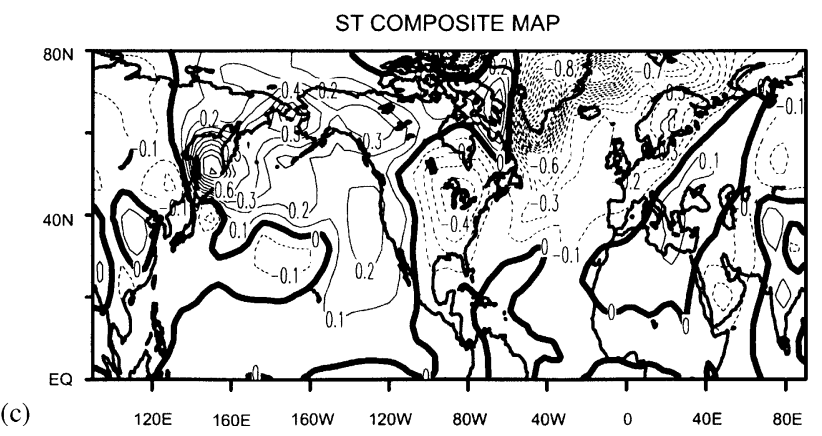

Fig. 7. (a) The time series of the surface temperature (ST) index. The index was defined as the difference between the northeastern Pacific (Fig. 5a) and northeastern Atlantic (Fig. 6a) ST indices where the mean value was subtracted. The arrow bar indicates the range of the \pm 1 standard deviation. (b) Composite map of SLP based on the ST index (a) (see text for details); unit is $\mathrm{hPa}$. (c) Composite map of surface temperature (ST) based on the ST index (a) (see text for details); unit is ${ }^{\circ} \mathrm{C}$. The 50 -yr mean ST and SLP data were used for the analysis.

\section{Summary and conclusion}

A set of alkenone SST records is analysed for the Holocene period. In general, the alkenone SST records show a basin scale warming in the North Pacific and a cooling in the North Atlantic over the last 7000 years. In the North Atlantic realm, the alkenone SST spatial pattern fits the modern NAO-related SST pattern: SST variations in the northeastern Atlantic are opposite in trend with those from the eastern Mediterranean Sea and the northern Red Sea. This trend is consistent with the northeastern Atlantic SST trend pattern for the Holocene period (Marchal et al., 2002), which has been attributed to a continuous weakening of the NAO-like atmospheric circulation during the Holocene (Rimbu et al., 2003). The opposing SST trends between the northeastern Atlantic and the northern Red Sea were also consistently accompanied by a warming in the tropical regions over the last 7000 years. Indeed, such heterogeneity of SST trends is coherent with coupled atmosphere-ocean circulation model simulations driven solely by the Earth's orbital parameters (Lorenz and Lohmann, 2004) and a continuous weakening of the Icelandic Low and altered winds in the Nordic Seas during the Holocene (Lohmann et al., 2004).

The most clearly defined alkenone SST pattern is an opposing trend with a long-term warming in the northeastern Pacific and a cooling in the northeastern Atlantic over the last 7000 years. The 2300 year long control simulation of the ECHO-G coupled atmosphere-ocean model also suggests that positive temperature anomalies in the northeastern Pacific were accompanied by negative anomalies in the northeastern Atlantic and vice versa. The comparable northeastern Pacific-Atlantic SST seesaw pattern between the alkenone SST data and the model results implies that the long-term SST variations were influenced by similar processes that caused centennial climate variability in the model simulation. A similar Pacific-Atlantic seesaw has also been reported by Kiefer et al. (2001) during Dansgaard-Oeschger events and by Weijer and Dijkstra (2003) in an eigenmode analysis of a global ocean circulation model. Further studies are necessary to better understand how inter-oceanic teleconnections are related to large-scale atmospheric teleconnentions and ocean circulation changes.

\section{Acknowledgements}

We would sincerely like to thank the GHOST contributors for providing their alkenone data, F. Sirocko for the 74KL sediment samples, and R. Kreutz and D. Grotheer for technical assistance in the Bremen University laboratory. Thanks go also to reviewers for their thorough comments. Financial support was provided by grants from the German Ministry of Research and Education (BMBF) through the GHOST project of DEKLIM (RCOM contribution No. 0151). 


\section{References}

Arz, H.W., Lamy, F., Pätzold, J., Müller, P.J., Prins, M., 2003. Mediterranean moisture soure for an Early-Holocene humid period in the Northern Red Sea. Science 300, 118-121.

Bard, E., Fairbanks, R.G., Arnold, M., Maurice, P., Duprat, J., Moyes, J., Duplessy, J.-C., 1989. Sea level estimates during the last deglaciation based on $\delta^{18} \mathrm{O}$ and accelerator mass spectrometry ${ }^{14} \mathrm{C}$ ages measured on Globigerina bulloides. Quaternary Research 31, 381-391.

Bard, E., Rostek, F., Turon, J.-L., Gendreau, S., 2000. Hydrological impact of Heinrich Events in the subtropical northeast Atlantic. Science 289, 1321-1324.

Barron, J.A., Heusser, L., Herbert, T., Lyle, M., 2003. High resolution climatic evolution of coastal Northern California during the past 16,000 Years. Paleoceanography 18, 1020, March 2003, doi:10.1029/2002PA000768.

Bond, G., Kromer, B., Beer, J., Muscheler, R., Evans, M.N., Showers, W., Hoffmann, S., Lotti-Bond, R., Hajdas, I., Bonani, G., 2001. Persistent solar influence on North Atlantic climate during the Holocene. Science 294, 2130-2133.

Brassell, S.C., Eglinton, G., Marlowe, I.T., Pflaumann, U., Sarnthein, M., 1986. Molecular stratigraphy: a new tool for climatic assessment. Nature 320, 129-133.

Cacho, I., Grimalt, J.O., Pelejero, C., Canals, M., Sierro, F.J., Flores, J.A., Shackleton, N.J., 1999. Dansgaard-Oeschger and Heinrich event imprints in Alboran Sea paleotemperatures. Paleoceanography $14,698-705$.

Cacho, I., Grimalt, J.O., Canals, M., Sbaffi, L., Schackleton, N.J., Shonfeld, J., Zahn, R., 2001. Variability of the Western Mediterranean sea surface temperatures during the last 25000 years and its connection with the Northern Hemisphere climatic changes. Paleoceanography 16, 40-52.

Calvo, E., Grimalt, J., Jansen, E., 2002. High resolution UK37 sea surface temperature reconstruction in the Norwegian Sea during the Holocene. Quaternary Science Reviews 21, 1385-1394.

Capotondi, L., Borsetti, A.M., Morigi, C., 1999. Foraminiferal ecozones: a high resolution proxy for the late Quaternary biochronology in the central Mediterranean Sea. Marine Geology 153, 253-274.

Chapman, M.R., Shackleton, N.J., Zhao, M., Eglington, G., 1996. Faunal and alkenone reconstructions of subtropical North Atlantic surface hydrography and paleotemperature over the last $28 \mathrm{kyr}$. Paleoceanography $11,343-357$.

deMenocal, P., Ortiz., J., Guilderson, T., Adkins, J., Sarnthein, M., Baker, L., Yaarusinsky, M., 2000. Abrupt onset and termination of the African Humid Period: rapid climate responses to gradual insolation forcing. Quaternary Science Reviews 19, 347-361.

Doose-Rolinski, H., Rogalla, U., Scheeder, G., Lücke, A., von Rad, U., 2001. High resolution temperature and evaporation changes during the late Holocene in the northeastern Arabian Sea. Paleoceanography 16, 358-367.

Emeis, K.-C., Struck, U., Schulz, H.-M., Rosenberg, R., Bernasconi, S., Erlenkeuser, H., Sakamoto, T., Martinez-Ruiz, F., 2000. Temperature and salinity variations of Mediterranean Sea surface waters over the last 16,000 years from records of planktonic stable oxygen isotopes and alkenone unsaturation ratios. Palaeogeography, Palaeoclimatology, Palaeoecology 158, 259-280.

Emeis, K.-C., Struck, U., Blanz, T., Kohly, A., Voß, M., 2003. Salinity changes in the central Baltic Sea (NW Europe) over the last 10000 years. The Holocene 13, 411-421.

Emeis, K.-C., Dawson, A., 2003. Holocene paleoclimate records over Europe and the North-Atlantic. The Holocene 13, 305-309.

Ghil, M., Allen, R.M., Dettinger, M.D., Ide, K., Kondrashov, D., Mann, M.E., Robertson, A., Saunders, A., Tian, Y., Varadi, F.,
Yoiou, O., 2002. Advanced spectral methods for climatic time series. Reviews of Geophysics 40 (1), 3.1-3.41.

Giunta, S., Emeis, K.-C., Negri, A., 2001. Sea-surface temperature reconstruction of the last 16,000 years in the Eastern Mediterranean Sea. Rivista Italiana di Paleontologia e Stratigrafia 107, 463-476.

Grootes, P.M., Stuiver, M., 1997. Oxygen 18/16 variability in Greenland snow and ice with $10^{3}-10^{5}$-year time resolution. Journal Geophysical Research 102, 26455-26470.

Grootes, P.M., Stuiver, M., White, J.M.C., Johnsen, S., Jouzel, J., 1993. Comparison of oxygen isotope records from the GISP2 and GRIP Greenland ice cores. Nature 366, 552-554.

Herbert, T.D., Schuffert, J.D., 2000. 16. Alkenone unsaturation estimates of sea-surface temperatures at site 1002 over a full glacial cycle. Proceedings of the Ocean Drilling Program, Scientific Results 165, 239-247.

Herbert, T.D., Schuffert, J.D., Andreasen, D., Heusser, L., Lyle, M., Mix, A., Ravelo, A.C., Stott, L.D., Herguera, J.C., 2001. Collapse of the California Current during glacial maxima linked to climate change on land. Science 293, 71-76.

Huang, C.-Y., Wu, S.-F., Zhao, M., Chen, M.-T., Wang, C.-H., Tu, X., Yuan, P.B., 1997. Surface ocean and monsoon climate variability in the south China Sea since last glaciation. Marine Micropaleontology 32, 71-94.

Hurrell, J.W., 1995. Decadal trends in the North Atlantic Oscillation: regional temperatures and precipitation. Science 269, 676-679.

Imbrie, J., Hays, J.D., Martinson, D.G., McIntyre, A., Mix, A.C., Morley, J.J., Pisias, N.G., Prell, W.L., Shackleton, N.J., 1984. The orbital theory of Pleistocene climate: support from a revised chronology of the marine $\delta^{18} \mathrm{O}$ record. In: Berger, A.L., Imbrie, J., Hays, J.D., Kulka, J., Saltzman, J. (Eds.), Milankovitch and Climate (Part. 1), NATO Advanced Science Institutes Series C: Mathematical and Physical Sciences, vol. 126. Reidel, Hingham, MA, pp. 269-305.

Kiefer, T., Sarnthein, M., Erlenkeuser, H., Grootes, P., Roberts, A., 2001. North Pacific response to millennial-scale changes in ocean circulation over the last $60 \mathrm{ky}$. Paleoceanography 16, 179-189.

Keigwin, L.D., 1998. Glacial-age hydrography for the far northwest Pacific Ocean. Paleoceanography 13, 323-339.

Kennett, J.P., Roark, E.B., Cannariato, K.G., Ingram, B.L., Tada, R., 2000. 21. Late Quaternary paleoclimatic and radiocarbon chronology, Hole 1017E, southern California Margin. Proceedings of the Ocean Drilling Program, Scientific Results 167, 249-254.

Kienast, S.S., McKay, J.L., 2001. Sea surface temperature in the subarctic Northeast Pacific reflect millennial-scale Climate Oscillations during the last 16 kyrs. Geophysical Research Letters 28, $1563-1566$.

Kim, J.-H., Schneider, R.R., 2004. GHOST global database for alkenone-derived Holocene sea-surface temperature records. http:// www.pangaea.de/Projects/GHOST/Holocene.

Kudrass, H.R., Hofmann, A., Doose, H., Emeis, K., Erlenkeuser, H., 2001. Modulation and amplification of climatic changes in the Northern Hemisphere by the Indian summer monsoon during the past 80 ky. Geology 29, 63-66.

Legutke, S., Voss, R., 1999. The Hamburg atmosphere-ocean coupled circulation model ECHO-G. DKRZ Report No. 18, Hamburg, Germany.

Lohmann, G., Lorenz, S., Prange, M., 2004. Northern high-latitude climate changes during the Holocene as simulated by circulation models. AGU Monographs, Bjerknes book about the Nordic Seas, in press.

Lorenz, S.J., Lohmann, G., 2004. Acceleration technique for Milankovitch type forcing in a coupled atmosphere-ocean circulation model: method and application for the Holocene. Climate Dynamics, doi:10.1007/S00382-004-0469-y. 
Lorenz, S.J., Kim, J.-H., Rimbu, N., Schneider, R.R., Lohmann, G., 2004. Orbitally driven insolation forcing on Holocene climate trends reassessed. Paleoceanography, submitted for publication.

Mantua, N., Hare, S., 2002. The Pacific Decadal Oscillation. Journal of Oceanography 58, 35-44.

Mantua, N.J., Hare, S.R., Zhang, Y., Wallace, J.M., Francis, R.C., 1997. A Pacific interdecadal climate oscillation with impacts on salmon production. Bulletin of the American Meteorological Society $78,1069-1079$.

Marchal, O., Cacho, I., Stocker, T.F., Grimalt, J.O., Calvo, E., Martrat, B., Shackleton, N., Vautravers, M., Cortijo, E., van Kreveld, S., Andersson, C., Koç, N., Chapman, M., Sbaffi, L., Duplessy, J.-C., Sarnthein, M., Turon, J.-L., Duprat, J., Jansen, E., 2002. Apparent long-term cooling of the sea surface in the Northeast Atlantic and Mediterranean during the Holocene. Quaternary Science Reviews 21, 455-483.

Martinson, D.G., Pisias, N.G., Hays, J.D., Imbrie, J., Moore, T.C., Shackleton, N.J., 1987. Age dating and the orbital theory of the ice ages: development of a high-resolution 0 to 300,000 year chronostratigraphy. Quaternary Research 27, 1-29.

Moy, C.M., Seltzer, G.O., Rodbell, D.T., Anderson, D.M., 2002. Variability of El Niño/Southern Oscillation activity at millennial timescales during the Holocene epoch. Nature 420, 162-165.

Müller, P.J., Kirst, G., Ruhland, G., von Storch, I., Rosell-Melé, A., 1998. Calibration of the alkenone palaeotemperature index $U_{37}^{K}$ based on core-tops from the eastern South Atlantic and the global ocean $\left(60^{\circ} \mathrm{N}-60^{\circ} \mathrm{S}\right)$. Geochimica et Cosmochimica Acta 62, $1757-1772$.

Oppo, D.W., McManus, J.F., Cullen, J.L., 2003. Deepwater variability in the Holocene epoch. Nature 422, 277-278.

Ostertag-Henning, C., Stax, R., 2000. 26. Data report: Carbonate records from sites 1012, 1013, 1017, and 1019 and alkenone-based sea-surface temperatures from site 1017. Proceedings of the Ocean Drilling Program, Scientific Results 167, 297-302.

Pelejero, C., Grimalt, J.O., 1997. The correlation between the UK37 index and sea surface temperatures in the warm boundary: the South China Sea. Geochimica et Cosmochimica Acta 61, 4789-4797.

Pelejero, C., Grimalt, J.O., Heilig, S., Kienast, M., Wang, L., 1999a. High-resolution UK37 temperature reconstructions in the South China Sea over the past 220 kyr. Paleoceanography 14, 224-231.

Pelejero, C., Kienast, M., Wang, L., Grimalt, J.O., 1999b. The flooding of Sundaland during the last deglaciation: imprints in hemipelagic sediments from the southern South China Sea. Earth Planetary Science Letters 171, 661-671.

Peterson, L.C., Haug, G.H., Murray, R.W., Yarincik, K.M., King, J.W., Bralower, T.J., Kameo, K., Rutherford, S.D., Pearce, R.B., 2000. 4. Late Quaternary stratigraphy and sedimentation at site 1002, Cariaco basin (Venezuela). Proceedings of the Ocean Drilling Program, Scientific Results 165, 85-99.

Prahl, F.G., Wakeham, S.G., 1987. Calibration of unsaturation patterns in long-chain ketone compositions for paleotemperature assessment. Nature 330, 367-369.

Prahl, F.G., Muehlhausen, L.A., Zahnle, D.L., 1988. Further evaluation of long-chain alkenones as indicators of paleoceanographic conditions. Geochimica et Cosmochimica Acta 52, 2303-2310.

Rimbu, R., Lohmann, G., Kim, J.-H., Arz, H.W., Schneider, R.R., 2003. Arctic/North Atlantic Oscillation signature in Holocene sea surface temperature trends as obtained from alkenone data. Geophysical Research Letters 30, 1280.

Rimbu, N., Lohmann, G., Lorenz, S.J., Kim, J.-H., Schneider, R.R., 2004. Holocene climate variability as derived from alkenone sea surface temperature and coupled ocean-atmosphere model experiments. Climate Dynamics, doi:10.1007/S00382-004-0435-8.
Rosell-Melé, A., Eglinton, G., Pflaumann, U., Sarnthein, M., 1995. Atlantic core-top calibration of the UK37 index as a sea-surface palaeotemperature indicator. Geochimica et Cosmochimica Acta 59, 3099-3107.

Rosell-Melé, A., Bard, E., Emeis, K.-C., Grimalt, J.O., Müller, P., Schneider, R., Bouloubassi, I., Epstein, B., Fahl, K., Fluegge, A., Freeman, K., Goñi, M., Güntner, U., Hartz, D., Hellebust, S., Herbert, T., Ikehara, M., Ishiwatari, R., Kawamura, K., Kenig, F., de Leeuw, J., Lehman, S., Mejanelle, L., Ohkouchi, N., Pancost, R.D., Pelejero, C., Prahl, F., Quinn, J., Rontani, J.-F., Rostek, F., Rullkötter, J., Sachs, J., Blanz, T., Sawada, K., Schulz-Bull, D., Sikes, E., Sonzogni, C., Ternois, Y., Versteegh, G., Volkman, J.K., Wakeham, S., 2001. Precision of the current methods to measure the alkenone proxy $\mathrm{UK}^{\prime} 37$ and absolute alkenone abundance in sediments: results of an interlaboratory comparision study. Geochemistry, Geophysics, Geosystems G 2, 2000GC000141.

Rühlemann, C., Mulitza, S., Müller, P.J., Wefer, G., Zahn, R., 1999. Warming of the tropical Atlantic Ocean and slowdown of thermohaline circulation during the last deglaciation. Nature 402, 511-514.

Sarnthein, M., van Kreveld, S., Erlenkeuser, H., Grootes, P.M., Kucera, M., Pflaumann, U., Schulz, M., 2003. Centennial-tomillennial-scale periodicities of Holocene climate and sediment injections off the western Barents shelf, $75^{\circ} \mathrm{N}$. Boreas 32 , 447-461.

Sawada, K., Handa, N., 1998. Variability of the path of the Kuroshio ocean current over the past 25,000 years. Nature 392, 592-595.

Schulz, M., Paul, A., 2002. Holocene climate variability on centennialto-millennial time scales: 1. Climate records from the NorthAtlantic Realm. In: Wefer, G., Berger, W., Behre, K.-E., Jansen, E. (Eds.), Climate development and history of the North Atlantic Realm. Springer, Berlin, Heidelberg, pp. 41-54.

Shackleton, N.J., 2000. The 100,000-year ice-age cycle identified and found to lag temperature, carbon dioxide and orbital eccentricity. Science 289, 1897-1902.

Siani, G., Paterne, M., Michel, E., Sulpizio, R., Sbrana, A., Arnold, M., Haddad, G., 2001. Mediterranean sea-surface radiocarbon reservoir age changes since the last glacial maximum. Science 294, $1917-1920$

Sirocko, F., Sarnthein, M., Erlenkeuser, H., Lange, H., Arnold, M., Duplessy, J.C., 1993. Century-scale events in monsoonal climate over the past 24,000 years. Nature 364, 322-324.

Sonzogni, C., Bard, E., Rostek, F., Lafont, R., Rosell-Melé, A., Eglinton, G., 1997. Core-top calibration of the alkenone index vs sea surface temperture in the Indian Ocean. Deep Sea Research II 44, 1445-1460.

Sperling, M., Schmiedl, G., Hemleben, C., Emeis, K.-C., Erlenkeuser, H., Grootes, P., 2003. Black Sea impact on the formation of eastern Mediterranean sapropel S1: evidence from the Marmara Sea. Palaeogeography, Palaeoclimatology, Palaeoecology 190, 9-21.

Ternois, Y., Kawamura, K., Ohkouchi, N., Keigwin, L., 2000. Alkenone sea surface temperature in the Okhotsk Sea for the last 15 kyr. Geochemical Journal 34, 283-293.

Thompson, D.W.J., Wallace, J.W., 1998. The Arctic Oscillation signature in the wintertime geopotential height and temperature fields. Geophysical Research Letters 25, 1297-1300.

Thompson, D.W.J., Wallace, J.M., Hegerl, G.C., 2000. Annular modes in the extratropical circulation, Part II: trends. Journal of Climate 13, 1018-1036.

von Rad, U., Schaaf, M., Michels, K.H., Schulz, H., Berger, W., Sirocko, F., 1999. A 5000-yr record of climate change in varved sediments from the oxygen minimum zone off Pakistan, Northeastern Arabian Sea. Quaternary Research 51, 39-53. 
von Storch, H., Zwiers, F.W., 1999. Statistical Analysis in Climate Research. Cambridge University Press, Cambridge, UK 735pp.

Wallace, J.M., Gutzler, D.S., 1981. Teleconnections in the geopotential height field during the Northern Hemisphere winter. Monthly Weather Reviews 109, 784-812.

Wang, L., Sarnthein, M., Erlenkeuser, H., Heilig, S., Ivanova, E., Kienast, M., Pflaumann, U., Pelejero, C., Grootes, P., 1999. East Asian monsoon during the late Quaternary: high-resolution sediment records from the South China Sea. Marine Geology $156,245-284$.

Weijer, W., Dijkstra, H.A., 2003. Multiple oscillatory modes of the global ocean. Journal of Physical Oceanography 33, 2197-2213.

Zhao, M., Beveridge, N.A.S., Shackleton, N.J., Sarnthein, M., Eglinton, G., 1995. Molecular stratigraphy of cores off northwest Africa: sea surface temperature history over the last $80 \mathrm{ka}$. Paleoceanography 10, 661-675. 